OPEN ACCESS

Edited by:

Pablo Fernández-Berrocal,

University of Malaga, Spain

Reviewed by:

Joyce Adkins,

AdBrook Group, USA

Dina Guglielmi,

University of Bologna, Italy

*Correspondence:

Annamaria Di Fabio

adifabio@psico.unifi.it

Specialty section:

This article was submitted to

Organizational Psychology,

a section of the journal

Frontiers in Psychology

Received: 14 March 2016

Accepted: 12 May 2016

Published: 30 May 2016

Citation:

Di Fabio A and Gori A (2016)

Developing a New Instrument for

Assessing Acceptance of Change.

Front. Psychol. 7:802

doi: 10.3389/fpsyg.2016.00802

\section{Developing a New Instrument for Assessing Acceptance of Change}

\author{
Annamaria Di Fabio * and Alessio Gori \\ Department of Education and Psychology (Psychology Section), University of Florence, Florence, Italy
}

This article focuses on the usefulness of going beyond the concept of resistance to change and capitalizing on the use of a model that includes positivity and acceptance of change. We first discuss the theoretical background of this new construct in the work and organizational fields and then evaluate the psychometric properties of a new measure for assessing acceptance of change. The results of exploratory factor analysis indicated a factor structure with five principal dimensions; besides confirmatory factor analysis (CFA) goodness of fit indices indicated a good fit of the model to the data. All the dimensions showed good values of internal consistency. The results of the present study indicate that the Acceptance of Change Scale (ACS) is a brief and easily administered instrument with good psychometric properties that can promote the development of clients' strengths and the growth of a sense of Self, thereby helping them choose their own way without losing any opportunities in their lives and their work.

Keywords: acceptance of change, resistance to change, acceptance of change scale, psychometric properties, positive psychology

\section{INTRODUCTION}

In modern societies, a person's ability to face change is highly valued at the individual level, in the world of work, and in society.

At the individual level, understanding and accepting change is crucial for personal development, particularly because coping with change is often very difficult for many individuals (Wanberg and Banas, 2000).

In today's rapidly changing world of work, people need to deal with change constructively as a good attitude to change can help them find ways of meeting challenges successfully thereby promoting their well-being (Van den Heuvel et al., 2013; Di Fabio et al., 2014; Di Fabio and Palazzeschi, 2015a). Indeed, at the societal level, people who accept change positively can more easily respond to the demands of modern societies. Some people view change as an opportunity to grow and learn with positive implications for their personal development, for creating readiness for change in them (e.g., Armenakis et al., 1993); for "successful planned change" (Miller et al., 1994) in the workplace; for promoting relational management (Di Fabio, 2015b; Di Fabio and Kenny, 2016), well-being (Di Fabio and Bucci, 2015), and psychological strengths (Di Fabio, 2011; Di Fabio and Kenny, 2012a,b; Di Fabio and Palazzeschi, 2012, 2015a; Di Fabio and Saklofske, 2014a,b; Di Fabio and Kenny, 2015); and for improving their relational civility (Di Fabio and Gori, in review).

Several researchers have identified factors that may be associated with people's openness to change (Miller et al., 1994; Judge et al., 1999; Wanberg and Banas, 2000) or resistance to change (Oreg, 2003), but little empirical work has been done in this area, especially as regards acceptance of change. In organizational psychology in particular, a body of literature has grown on resistance 
to change (Dent and Goldberg, 1999; Folger and Skarlicki, 1999; Oreg, 2003, 2006; Ford et al., 2008; van Dam et al., 2008), and most of the reported studies subscribe to the definition of resistance to change as a "restraining force moving the direction of maintaining the status quo" (Lewin, 1952; Piderit, 2000, p. 784).

The present study, however, went beyond the concept of resistance to change to consider the concept of positive change, namely the acceptance of change $(\mathrm{AC})$, in line with recent advances in positive psychology (Seligman and Csikszentmihalyi, 2000; Compton, 2005) and bearing in mind Maslow's theory of needs (1954) and evolutionary theory (Maslow, 1954). To quote Zuckerman (2014), "change is a fact of life, that people can resist or accept, considering that the world around us inevitably will change" (Zuckerman, 2014, p. 1). Based on this premise, the ability to accept change could be a very useful resource in many spheres of life at the intra- and inter-individual level as well as the global level.

A new construct, up till now missing in the psychology literature, is therefore needed to study the phenomenon of change. This new construct is the acceptance of change (AC), and researchers are currently engaged in verifying the main psychometric properties of a new multidimensional scale for assessing $\mathrm{AC}$ in its different forms.

\section{ANALYSIS OF DIFFERENT CONSTRUCTS IN RELATION TO AC}

A review of the literature on constructs that could have a bearing on AC will help explain why we defined a new construct and developed a new measure for its evaluation. In particular, we would like to focus on research on the process of change in the work and organizational fields on the basis of different variables seemingly contributing to change.

\section{The Concept of Resistance to Change (RC)}

The first studies on resistance to change in work and organizational psychology were published in the late 1940s and early 1950s (Coch and French, 1948). Later studies analyzed resistance to change as a defense mechanism (Zander, 1950) and its social impact as such a mechanism (Lawrence, 1954). Early research on change focused primarily on how organizations as a whole reacted to organizational change (Armenakis and Bedeian, 1999) and not on individuals' reaction or attitude to such change (Vakola et al., 2004).

More recent studies have begun to explore resistance to change variables from an individual perspective (Judge et al., 1999; Piderit, 2000; Oreg, 2003; Lamm and Gordon, 2010) although problems have emerged in the analysis of this construct (Dent and Goldberg, 1999; Piderit, 2000). Dent and Goldberg (1999) point out that previous studies concentrated on ways of preventing resistance to change phenomena, while Piderit (2000) states that earlier researchers considered resistance to change a behavioral, emotional, or cognitive reaction and proposed an integrated model for such resistance. Oreg (2003) defines resistance to change as the individual tendency to resist or avoid change, to devalue change in general, and to label it as negative regardless of the context (Oreg, 2003). All these studies investigated individuals' attitudes in terms of resistance to change. The present study, by contrast, explored and conceptualized a new construct, acceptance of change (AC), and developed a new measure for assessing it.

\section{The Concept of Openness to Change}

Openness to change is a construct introduced by Wanberg and Banas (2000) based on cognitive adaptation theory, which holds that individuals with the highest levels of well-being during stressful life events are those who also have high levels of selfesteem, optimism, and perceived control (Wanberg and Banas, 2000). Several authors have pointed out also the usefulness of psychological resources in building a resilient personality (Major et al., 1998) and being open to change (Taylor and Brown, 1988; Judge et al., 1997).

In describing the construct of openness to change in a reorganizing workplace, Wanberg and Banas (2000) list several variables including receipt of information on the change, participation in the change process, self-efficacy in the belief to be able to change, social support, and the personal impact of the change. According to these authors, the mentioned variables are often more responsive to organizational intervention than the other variables in cognitive adaptation theory (self-esteem, generalized perceived control, and optimism) (Wanberg and Banas, 2000).

\section{THE ACCEPTANCE OF CHANGE (AC): A NEW CONSTRUCT}

The literature reveals major consensus regarding the role of human nature in resistance to change (Coch and French, 1948; Zander, 1950; Conner, 1992; Oreg, 2003). Some authors, however, consider resistance to change counterproductive (Dent and Goldberg, 1999).

Acceptance of change (AC) can be seen as the tendency to embrace rather than shy away from change because acceptance is regarded as positive for a person's well-being. AC thus stems from the belief that, in their work and other activities, people who are able to accept change often find that the change has a positive impact on their working lives and their resource levels. In terms of Maslow's theory of needs (1954) and evolutionary theory, AC can be conceptualized as a multidimensional, dynamic construct, a core of positive characteristics that can be improved and acted on preventively (Maslow, 1954). In terms of positive psychology $\mathrm{AC}$, can be viewed as a chance to grow and learn (Seligman and Csikszentmihalyi, 2000; Wanberg and Banas, 2000).

In defining this new construct and its dimensions, we relied on the above conceptualization and, in particular, on studies on change in the work and organizational fields, analyzing the variables seemingly contributing to change (e.g., Goldsmith, 1984; Mallinckrodt and Fretz, 1988; Lau and Woodman, 1995; Oreg, 2003; Vakola et al., 2004; Jordan, 2005; Visser, 2010). Given that the traditional approach involved investigating individuals' attitudes in terms of resistance to change (Oreg, 2003), we 
considered it appropriate in this study to investigate these attitudes in terms of positive characteristics and dimensions for implementing change. The identified dimensions were: Predisposition to Change; Support for Change; Change Seeking; Positive Reaction to Change; and Cognitive Flexibility.

\section{Predisposition to Change}

Predisposition to change is the ability people have to learn from change and to use change to improve the quality of their lives. Self-determination theory holds that the drive for change can be intrinsically and extrinsically motivated (Deci and Ryan, 1985, 2000) and that people will be supported by their natural or intrinsic tendencies to behave in effective and healthy ways and to cope with change. Gagné and Deci (2005) found a link between motivation and several organizational variables including persisting with and maintaining behavior change (Visser, 2010).

\section{Support for Change}

Support for change refers to social support perceived to be received from others when facing challenges. Many researchers stress the importance of social support in promoting well-being and life satisfaction (Mallinckrodt and Fretz, 1988; Shaw et al., 1993). Perceived social support refers to people's perception that they are receiving help and support from others, for example the support of parents and friends perceived to be received, particularly emotional support (reassurance, encouragment) and cognitive support (advice, suggestions, comparisons).

\section{Change Seeking}

The process of change frequently leads to an increase in mental and physiological stimulation in people. Zuckerman (2014) argues that some individuals seek change and that this could have adaptive value for those who are able to acquire and retain information. According to Maslow's theory of needs (1954)which stresses the importance of growth, change, and openness to new experiences-people are driven toward change by their own needs. Moreover, several studies have found that innovative individuals tend to find new solutions to problems outside the normal framework of problem solving (Kirton, 1980, 1989) and often exhibit a need for new stimuli (Goldsmith, 1984; Oreg, 2003).

Change seeking appears to be a key factor in the acceptance of change (AC) process because individuals with a high level of AC generally have a high level of novelty seeking. Change seeking predisposes individuals not only to seek change, but also to accept and integrate life and work changes not necessarily originating from them.

\section{Positive Reaction to Change}

The broaden-and-build theory (Fredrickson, 2001, 2004) holds that positive emotions broaden people's awareness and encourage them to try new things. According to Fredrickson (2001, 2004), such positive emotions incline people toward new possibilities and enable them to make good choices. This theory partly inspired the present acceptance of change (AC) construct-and particularly the positive reaction to change (PRC) dimensionbecause positive emotions predispose people to experience change positively and to benefit from it.

Jordan (2005) argues that change is inherently emotional and that there is, accordingly, a theoretical justification for the notion that people with greater emotional intelligence tend to be more efficient in managing change compared to those with lower emotional intelligence. Vakola et al. (2004) claim also that emotional intelligence can contribute to organizational change and that it is therefore a critical success factor in the change process (Di Fabio and Palazzeschi, 2009; Di Fabio et al., 2016). The PRC factor thus plays a key role in the acceptance of change.

\section{Cognitive Flexibility}

Cognitive flexibility (CF) can be defined as the mental ability to switch between different concepts (Scott, 1962) or to adapt cognitive processing strategies (Cañas et al., 2005).

Cognitive reaction to change refers to what people think about change, and cognitive flexibility (CF) refers to people's ability to think about multiple concepts simultaneously, to change decisions if this is advantageous, and to change plans and routines easily. Little is known about CF in relation to change because, in the past, researchers focused primarily on rigidity and closemindedness, which are prominent factors in people's resistance to change (Lau and Woodman, 1995; Oreg, 2003).

\section{METHOD}

\section{Participants and Procedure}

There were 261 participants in the present study (148 men, 103 women) with a mean age of 37.36 years old $(S D=17.74)$. The sample consisted of 141 workers (124 men) and 120 students (96 women) of the University of Florence.

The participants completed all the instruments discussed in the Measures Section (below), which were administered in line with privacy norms. The participants' anonymity was guaranteed, and written informed consent was obtained from them after a full description of the study. The participants were told they could leave the study at any time and that there would be no payment for participating. The study adhered to the latest version of the Declaration of Helsinki revised in Fortaleza [World Medical Association (WMA), 2013] with regard to ethical standards for research.

\section{Measures}

\section{Acceptance of Change Scale (ACS; Di Fabio and Gori, in review)}

The Acceptance of Change Scale (ACS) is a self-report measure that assesses the tendency of clients to accept or move toward change. The dimensions of the measure are Positive Reaction to Change, Change Seeking, Cognitive Flexibility, Predisposition to Change, and Support for Change. The ACS uses a 5-point Likerttype scale $(1=$ not at all, $2=$ a little, $3=$ somewhat, $4=$ much, $5=$ a great deal) that consists of 20 items (e.g., "When I am faced with a change, I can see things from multiple perspectives," "I normally seek different ways to do the same things in my daily routine," "I am able to give new meanings to the things that I 
have been doing for a long time," "It's easy for me to change my mind when I realize that I am wrong"). This scale can be used in the work and organizational fields and in all situations where it is necessary to promote change (e.g., human resources, counseling, empowerment) in order to help people understand themselves better and find their own way to manage their life and work opportunities.

\section{Intrapreneurial Self-Capital Scale (ISCS; Di Fabio, 2014a)}

Intrapreneurial self-capital is defined as a core of individual intrapreneurial resources used to cope with career and life construction challenges and includes dimensions of core selfevaluation, hardiness, creative self-efficacy, resilience, goal mastery, decisiveness, and vigilance (Di Fabio, 2014a). The Intrapreneurial Self-Capital Scale was developed by Di Fabio (2014a) to measure this new construct. The ISCS uses a 5-point Likert-type scale $(1=$ strongly disagree, $2=$ disagree, $3=$ neither agree nor disagree, $4=$ agree, $5=$ strongly agree) that consists of 28 items (e.g., "I am able to deal with most of my problems," "I am able to improve the ideas produced by others," "I am able to achieve objectives despite obstacles," "One of my goals in training is to learn as much as I can"). In the present study, we used the Italian version of this measure, which showed good internal consistency ( $a=0.86$ ) (Di Fabio, 2014a).

\section{Psychological Self-Capital Scale (PS; Luthans et al., 2007)}

Psychological capital is a new construct measured with the Psychological Capital Questionnaire 24 (PCQ-24). This measure of 24 items has four subscales: (1) Efficacy/Confidence (e.g., "I feel confident contributing to discussions about the organization's management"), (2) Hope (e.g., "I can think of many ways to reach my current work goals"), (3) Optimism (e.g., "I'm optimistic about what will happen to me in the future regarding work"), and (4) Resilience (e.g., "I usually take stressful things at work in my stride"). Each of these subscales consists of six items with response options on a six-point Likert scale ranging from 1 (strongly disagree) to 6 (strongly agree). The PCQ-24 has good psychometric properties, also in its Italian version, which was used in the present study (hope $=0.75$; efficacy $=0.78$; resilience $=0.70$; optimism $=0.77$; the overall scale $=0.81$ ) (Alessandri et al., 2015).

\section{Flourishing Scale (FS; Diener et al., 2010)}

The Flourishing Scale (FS) is a self-report measure consisting of eight items that assess respondents' self-perceived success in important areas of their lives such as relationships, self-esteem, purpose, and optimism. The response options are on a 6-point Likert scale ranging from 1 (strongly disagree) to 7 (strongly agree). Examples of items are "My social relationships are supportive and rewarding," "I lead a purposeful and meaningful life," "I am optimistic about my future." The FS showed a unidimensional structure with good reliability (Diener et al., 2010), and the Italian version of the scale (Di Fabio, 2016a) also demonstrated good reliability $(a=0.88)$.

\section{Positive Relational Management Scale (PRMS;}

\section{Di Fabio, 2015b)}

The Positive Relational Management Scale (PRMS) is a measure consisting of 12 items on a 5-point Likert scale ranging from 1 (strongly disagree) to 5 (strongly agree). The PRMS is used to assess three dimensions (respect, caring, connection) and has a total score (e.g., Respect: "I keep a balance between respect toward others and toward myself"; Caring: "I often take care of others"; Connection: "I have good relationships with my family"). The psychometric properties of the scale are good, also in its Italian version $($ respect $=0.81$; caring $=0.79$; connection $=0.80$; PRMS total $=0.84)($ Di Fabio, 2015b).

\section{Satisfaction with Life Scale (SWLS; Diener et al., 1985)}

The Satisfaction With Life Scale (SWLS) is a self-report instrument that measures global life satisfaction. It consists of five items on a seven-point Likert scale with higher values corresponding to higher degrees of life satisfaction. Examples of the items are "I am satisfied with my life," "The conditions of my life are excellent." The psychometric properties of the SWLS are good, and different studies have reported a unidimensional structure for this instrument (Diener et al., 1985; Vera-Villarroel et al., 2012). The Italian version of the SWLS $(a=0.85)$ was used in the study (Di Fabio and Gori, 2015).

\section{Multidimensional Scale of Perceived Social Support (MSPSS; Zimet et al., 1988)}

The MSPSS consists of 12 items on a 7-point Likert-type scale ranging from $1=$ strongly disagree to $7=$ strongly agree. It measures perceived support related to three main domains: family, friends, and a significant other. Examples of the items are "My family works very hard to help me," "I can speak about my problems with my friends," "When I need someone, there is always a special person who stands by me." Higher scores suggest greater levels of perceived social support. The MSPSS has been found to have good psychometric properties in several studies with different samples (Zimet et al., 1988, 1990). The Italian version of the scale was used in this study and reported excellent internal consistency for the three factors: family $(\alpha=0.91)$, friends $(\alpha=0.93)$, and significant other $(\alpha=0.88)$, and the total score $(\alpha=0.92)$ (Di Fabio and Palazzeschi, 2015b).

\section{Ten Item Personality Inventory (TIPI; Gosling et al., 2003)}

The Ten Item Personality Inventory (TIPI) was developed using descriptors related to the Big Five measures with each item consisting of two adjectives, separated by a comma, rated on a 7-point likert scale ranging from 1 (strongly disagree) to 7 (strongly agree). TIPI assesses the following dimensions linked to the Big Five measures: Extraversion (E) (e.g., "I see myself as extraverted, enthusiastic"), Agreeableness (A) (e.g., "I see myself as sympathetic, warm"), Conscientiousness (C) (e.g., "I see myself as dependable, self-disciplined"), Neuroticism (N) (e.g., "I see myself as calm, emotionally stable"), Openness (O) (e.g., "I see myself open to new experiences, complex"). The Italian version of this brief measure was used in the study and showed good values 
of internal reliability $(\mathrm{E}=0.82 ; \mathrm{A}=0.78 ; \mathrm{C}=0.79 ; \mathrm{N}=0.71$; $\mathrm{O}=0.74)$ (Di Fabio et al., 2016).

\section{Rosenberg Self-Esteem Scale (RSES; Rosenberg, 1965)}

The Rosenberg Self-Esteem Scale (RSES) is a ten-item scale for assessing global self-esteem with items answered on a 4-point Likert scale ranging from strongly agree to strongly disagree (e.g., "On the whole, I am satisfied with myself", "I have a positive attitude toward myself."). The psychometric properties of the RSES as reported in several studies are good (Corwyn, 2000). The Italian version of the RSES $(a=0.84)$ was used in the present study (Prezza et al., 1997).

\section{Insight Orientation Scale (IOS; Gori et al., 2015)}

The Insight Orientation Scale (IOS) is a brief measure consisting of seven items that assess clients' insight capacity, their behaviors, and their feelings and opinions about this construct (Gori et al., 2015). The response format is a 5 -point Likert scale $(1=$ "not at all," $2=$ "a little;" $3=$ "somewhat;" $4=$ "a lot," and $5=$ "a great deal") (e.g., "I am aware of the things I am doing," "I am able to solve difficult problems"). The IOS showed good psychometric properties ( $a=0.77)$ (Gori et al., 2015).

\section{Resistance to Change Scale (RCS; Oreg, 2003)}

The Resistance to Change Scale (RCS) is a measure consisting of 21 items that are responded to on a 5-point Likert-type scale ranging from $1=$ absolutely disagree to $5=$ absolutely agree (e.g., "Changing plans seems like a real hassle to me," "I like to do the same old things rather than try new and different ones"). The measure identifies three factors: routine seeking, emotional reaction to imposed change, and cognitive rigidity. The Cronbach's alphas in the study were 0.70 for routine seeking, 0.67 for emotional reaction to imposed change, and 0.66 for cognitive rigidity. The Italian version of the RCS (Di Fabio and Bernaud, 2007) was used in the study.

\section{Authenticity Scale (AS; Wood et al., 2008)}

The Authenticity Scale (AS) is a measure consisting of 12 items with a response format on a 7-point Likert scale ranging from $1=$ does not describe me at all to $7=$ describes me very well. The measure assesses Authenticity in terms of three dimensions (selfalienation, authentic living, and accepting external influence) and a total score (e.g., "I am true to myself in most situations"). The Italian version of AS (Di Fabio, 2014b) was used in the study and showed good psychometric properties $(a=0.77)$ (Di Fabio, 2014b).

\section{Data Analysis}

Factor analysis was used to identify the underlying dimensions of the ACS, using various criteria for item selection according to the number of selected factors and item factor loadings. In order to verify some assumptions, prior to exploratory factor analysis (EFA), we analyzed the Bartlett's Test of Sphericity and the Kaiser-Meyer-Olkin's (KMO) Measure of Sampling Adequacy to assess if the items were significantly correlated and shared sufficient variance to justify factor extraction. Principal axis factoring was selected as the method of factor extraction with oblique rotation (promax criterion) to obtain a simple structure as there was no theoretical assumption to suggest that the factors were independent of each other. Eigenvalues $>1$, the Kaiser criterion, and the screen test were checked for agreement (Giannini et al., 2011), and their salience was determined by applying the following criteria: (a) a factor loading of at least 0.3 on the primary factor, ensuring a high degree of association between the item and the factor; (b) a difference of 0.3 between loading on the primary factor and loading on other factors, ensuring that each item could be considered salient to one factor when an item was loading simultaneously on two factors; (c) a minimum of three items for each factor thus ensuring meaningful interpretation of stable factors (Craparo et al., 2015). The standard Pearson correlation coefficient was used to investigate to what extent the factor scores were intercorrelated. The reliability of the scale, in terms of internal consistency, was calculated by means of the alpha coefficient. A confirmatory factor analysis (CFA) was performed using maximum likelihood (ML) estimation procedures. To assess the closeness of the hypothetical model to the empirical data statistically, multiple goodness-of-fit indexes were used, including the ratio of the chisquare to degrees of freedom $(\chi 2 / d f)$, the Tucker-Lewis Index (TLI), the Comparative Fit Index (CFI), the Standardized Root Mean Square Residual (SRMR), and the Root Mean Square Error of Approximation (RMSEA). Bentler and Bonnet (1980) contend that values $>0.90$ indicate good fit for the TLI ( $\mathrm{Hu}$ and Bentler, 1999) contend that CFI values $>0.90$ are needed; and Byrne (1994) contends that a cutoff of 0.93 should indicate a good fit. SRMR and RMSEA values $<0.08$ (Browne and Cudeck, 1993 ), and ideally equal to or $<0.05$, are interpreted as indicating models that fit well (Steiger, 1990; Schermelleh-Engel et al., 2003; Giannini et al., 2011). Several aspects of concurrent validity were verified using the Pearson's $r$ coefficient.

\section{RESULTS}

An examination of the scree plot (Cattell, 1966), and percentage of variance accounted for, revealed that as many as five factors should be retained for rotation. The exploratory factor analysis (EFA) (promax rotation) showed a factor structure with five principal dimensions (eigenvalues $>1 ; 6.52,2.09,1.47,1.33,1.23$ ), with $63.21 \%$ of total variance explained.

Factor 1 (Predisposition to Change), with four items loading above 0.56 , had an eigenvalue of 6.52 and accounted for $32.58 \%$ of the total variance explained. Factor 2 (Support for Change), with four items loading above 0.41, had an eigenvalue of 2.09 and accounted for $10.46 \%$ of the total variance explained. Factor 3 (Change Seeking), with four items loading above 0.54 , had an eigenvalue of 1.47 and accounted for $7.36 \%$ of the total variance explained. Factor 4 (Positive Reaction to Change), with four items loading above 0.40 , had an eigenvalue of 1.33 and accounted for $6.65 \%$ of the total variance explained. Factor 5 (Cognitive Flexibility), with four items loading above 0.46 , had an eigenvalue of 1.23 and accounted for $6.15 \%$ of the total variance explained. The factor structure matrix shows the five independent factors of the questionnaire (Table 1). The revealed dimensions correlated 
TABLE 1 | Factor structure matrix of the Acceptance of Change Scale (ACS).

\begin{tabular}{|c|c|c|c|c|c|}
\hline $\begin{array}{l}\text { 10. Thinking about new plans is easy for me } \\
\text { Pensare a nuovi piani è facile per me }\end{array}$ & 0.904 & & & & \\
\hline $\begin{array}{l}\text { 9. I easliy identify alternative paths } \\
\text { Individuo percorsi alternativi con facilità }\end{array}$ & 0.891 & & & & \\
\hline $\begin{array}{l}\text { 12. I am able to take all the opportunities that occur to me Sono in } \\
\text { grado di afferrare tutte le opportunità che mi si presentano }\end{array}$ & 0.560 & & & & \\
\hline $\begin{array}{l}\text { 18. I trust the people close to me when faced with change } \\
\text { Mi fido delle persone a me vicine di fronte ai cambiamenti }\end{array}$ & & 0.862 & & & \\
\hline $\begin{array}{l}\text { 17. I can compare myself with other people important to me when } \\
\text { facing change } \\
\text { Posso confrontarmi con altre persone per me importanti di fronte ai } \\
\text { cambiamenti }\end{array}$ & & 0.669 & & & \\
\hline $\begin{array}{l}\text { 20. I can handle the changes in relationships with others Riesco a } \\
\text { gestire } i \text { cambiamenti nei rapporti con gli altri }\end{array}$ & & 0.415 & & & \\
\hline $\begin{array}{l}\text { 4. Although I do not see the benefits, I cannot wait to change Anche } \\
\text { se non vedo benefici, non vedo l'ora di cambiare }\end{array}$ & & & 0.867 & & \\
\hline $\begin{array}{l}\text { 3. I am looking for changes in my life, even when things are going well } \\
\text { Sono in cerca di cambiamenti nella mia vita, anche quando le cose } \\
\text { vanno bene }\end{array}$ & & & 0.746 & & \\
\hline $\begin{array}{l}\text { 1. I am always looking for changes in my everyday life } \\
\text { Sono sempre in cerca di cambiamenti nella mia vita di tutti i giorni }\end{array}$ & & & 0.597 & & \\
\hline $\begin{array}{l}\text { 16. I am aware of mutations that involve the change Sono } \\
\text { consapevole delle modifiche che comporta il cambiamento }\end{array}$ & & & & 0.675 & \\
\hline $\begin{array}{l}\text { 14. I am able to tolerate even the negative aspects of change } \\
\text { Sono in grado di tollerare anche gli aspetti negativi del cambiamento }\end{array}$ & & & & 0.566 & \\
\hline $\begin{array}{l}13 \text { I can find the positives in changes that are apparently negative } \\
\text { Riesco a trovare lati positivi nei cambiamenti che sono } \\
\text { apparentemente negativi }\end{array}$ & & & & 0.405 & \\
\hline $\begin{array}{l}\text { 6. My opinions may have changed } \\
\text { Le mie opinioni possono cambiare }\end{array}$ & & & & & 0.771 \\
\hline $\begin{array}{l}\text { 5. If necessary, it is not difficult for me to change my mind } \\
\text { Se necessario, non è difficile per me cambiare idea }\end{array}$ & & & & & 0.628 \\
\hline $\begin{array}{l}\text { 8. When I've made an important decision, I can change it if it involves } \\
\text { an advantage } \\
\text { Quando ho preso una decisione importante posso cambiarla, se } \\
\text { questo comporta un vantaggio }\end{array}$ & & & & & 0.513 \\
\hline $\begin{array}{l}\text { 7. It's easy for me to change my mind when I realize that I am wrong } \\
\text { E' facile per me cambiare idea quando mi rendo conto che sono in } \\
\text { errore }\end{array}$ & & & & & 0.459 \\
\hline$\%$ explained variance & $32.58 \%$ & $10.46 \%$ & $7.36 \%$ & $6.65 \%$ & $6.15 \%$ \\
\hline
\end{tabular}

*/talian version of the scale. 
significantly and showed good values (from $r=0.207, p<0.01$, to $r=0.510, p<0.01$ ) (Table 2).

The goodness-of-fit indices showed a good fit of the model to the data. Although the chi-square was significant, the other goodness-of-fit indices showed satisfactory and good values $\left(x^{2} / \mathrm{df}=1.81 p<0.001 ; \mathrm{CFI}=0.94 ; \mathrm{TLI}=0.92 ; \mathrm{SRMR}=0.05 ;\right.$ RMSEA $=0.05)$.

The reliability of the scales, calculated using the Cronbach's alpha coefficient, indicated good values of internal consistency (Predisposition to Change, $a=0.83$; Support for Change, $a=0.79$; Change Seeking, $a=0.80$; Positive Reaction to Change, $a=0.75$; Cognitive Flexibility, $a=0.72$, and the overall scale $=0.88)$.

The ACS showed strong correlations with the measures used to assess some aspects of concurrent validity (Tables 3,4 ).

\section{DISCUSSION}

People in the twenty-first century need the skills and resources to manage uncertainty and to face change in the most adaptive way (Arnoux-Nicolas et al., 2016; Di Fabio and Maree, 2016). This is even more important where the degree of uncertainty is high, for example at work. Work and organizational psychologists tend to see change as a process of gradual adaptation when, for example, individuals in organizations react to internal and external pressures (Demers, 2007) or when change results from selections made in terms of evolutionary theory (Child and

TABLE 2 | Intercorrelations of the ACS dimensions.

\begin{tabular}{lcccc}
\hline & $\mathbf{1}$ & $\mathbf{2}$ & $\mathbf{3}$ & $\mathbf{4}$ \\
\hline 1. Predisposition to change & 1 & & & \\
2. Support for change & $0.469^{\star \star}$ & 1 & & \\
3. Change seeking & $0.440^{\star \star}$ & $0.207^{\star \star}$ & 1 & \\
4. Positive reaction to change & $0.510^{\star \star}$ & $0.449^{\star \star}$ & $0.406^{\star \star}$ & 1 \\
5. Cognitive flexibility & $0.475^{\star \star}$ & $0.317^{\star \star}$ & $0.375^{\star \star}$ & $0.455^{\star \star}$ \\
\hline${ }^{* *} p<0.01$. & & & &
\end{tabular}

TABLE 3 | Summary of the correlation between the ACS and ISC, PSC, F, IOS, PSR, MSPSS.

\begin{tabular}{|c|c|c|c|c|c|c|}
\hline & ISCS & PSCS & FS & IOS & PRMS & MSPSS \\
\hline $\begin{array}{l}\text { 1. Predisposition to } \\
\text { change }\end{array}$ & $0.550^{\star \star}$ & $0.611^{\star \star}$ & $0.428^{\star \star}$ & $0.437^{\star \star}$ & $0.401^{\star *}$ & $0.309^{* \star}$ \\
\hline $\begin{array}{l}\text { 2. Support for } \\
\text { change }\end{array}$ & $0.425^{\star \star}$ & $0.361^{\star \star}$ & $0.354^{* \star}$ & $0.274^{\star \star}$ & $0.406^{\star \star}$ & $0.458^{\star *}$ \\
\hline 3. Change seeking & $0.375^{\star \star}$ & $0.360^{\star \star}$ & $0.208^{\star *}$ & $0.328^{\star \star}$ & $0.199^{\star *}$ & 0.094 \\
\hline $\begin{array}{l}\text { 4. Positive reaction } \\
\text { to change }\end{array}$ & $0.440^{* *}$ & $0.463^{\star \star}$ & $0.332^{* *}$ & $0.434^{\star \star}$ & $0.301^{\star *}$ & 0.119 \\
\hline 5. Cognitive flexibility & $0.357^{\star \star}$ & $0.405^{\star \star}$ & $0.179^{* \star}$ & $0.376^{\star \star}$ & $0.229^{\star \star}$ & 0.117 \\
\hline AC total score & $0.591^{\star \star}$ & $0.604^{\star \star}$ & $0.411^{\star *}$ & $0.507^{\star \star}$ & $0.420^{\star \star}$ & $0.300^{\star \star}$ \\
\hline
\end{tabular}

${ }^{\star \star} p<0.01$. ISCS, Intrapreneurial Self-Capital Scale; PSCS, Psychological Self-Capital Scale; FS, Flourishing Scale; IOS, Insight Orientation Scale; PRMS, Positive Relational Management Scale; MSPSS, Multidimensional Scale of Perceived Social Support.
Kieser, 1981; Hrebiniak and Joyce, 1985; Demers, 2007; Dunican, 2015). According to Topping (2002), change implies uncertainty, and uncertainty can cause fear. However, acknowledging uncertainty can lead to the acceptance of challenges (Geller, 2002; Dunican, 2015). Some researchers place more emphasis on the predisposition of people to accept or resist change (Michel et al., 2013) than on other factors such as leadership or the management of functional boundaries (Huczynski and Buchanan, 2001; Hoag et al., 2002; Burnes, 2003).

Acceptance of change as an individual reaction offers opportunities for future research as acceptance of change as opposed to resistance to change can promote people's effective and lifelong self and relational management (Di Fabio, 2015b; Di Fabio and Kenny, 2016). In other words, while recognizing the importance of the Oreg's (2003) resistance to change construct, in this study we wanted to turn the focus from negative to positive in order to emphasize the preventive perspective in psychology (Hage et al., 2007; Kenny and Hage, 2009; Di Fabio, 2015a; Di Fabio and Kenny, 2016) and to underline the importance of positive psychology (Seligman and Csikszentmihalyi, 2000).

The study accordingly set out to develop a new measure for assessing acceptance of change and its psychometric properties. The EFA showed a good structure with five principal dimensions: Predisposition to Change; Support for Change; Change Seeking; Positive Reaction to Change; and Cognitive Flexibility. Nunnally and Bernstein (1994) found that these dimensions showed good reliability; in fact, despite the reduced number of items, each dimension presented a good Cronbach's alpha.

The CFA also revealed a good fit of the model to the empirical data, as indicated by the fit indices. In particular, the CFA results showed that the SRMS and RMSEA were equal to 0.05, indicating a good fit (Browne and Cudeck, 1993; MacCallum et al., 1996). The CFI index indicated a good fit too (Byrne, 1994) and the TLI index a satisfactory fit (Bentler and Bonnet, 1980).

Correlations between the ACS and the measures used to verify some aspects of concurrent validity showed good values: all the relationships between the variables under investigation were in the right direction and with the right significance. In particular, the relationships between the ACS and these measures indicated that change is strictly related to individual intrapreneurial resources (Intrapreneurial Self-Capital Scale), to self-capital (Psychological Self-Capital Scale), to insight capacity (Insight Orientation Scale), to self-perceived success (Flourishing Scale), to life satisfaction (Satisfaction With Life Scale), and to openness (TIPI-Openness). Acceptance of change is thus particularly important in individual resource construction. Further studies are needed to explore these relationships in greater depth.

Also, the strong, negative correlation between the ACS and the Resistance of Change Scale (RCS) indicated the good divergent validity of the ACS.

Regarding the limitations of the present study, the major limitation was the relatively small number of participants. The use of so many instruments also burdened the administration process. However, at the same time, the large number of scales used in the study to assess aspects of concurrent validity could be viewed as a strength because it enabled the comparison of many different constructs thus providing additional information. 
TABLE 4 | Summary of the correlation between the two parts of the ACS and I-TIPI, RSES, SWLS, AS, RCS.

\begin{tabular}{|c|c|c|c|c|c|c|c|c|c|}
\hline & TIPIE & TIPIA & TIPIC & TIPIES & TIPIO & RSES & SWLS & AS & RCS \\
\hline 1. Predisposition to change & $0.290^{\star \star}$ & $0.295^{\star \star}$ & $0.254^{\star \star}$ & $0.392^{\star \star}$ & $0.438^{\star *}$ & $0.433^{\star \star}$ & $0.432^{\star \star}$ & $193^{\star \star}$ & $-0.431^{\star *}$ \\
\hline 2. Support for change & $0.218^{\star \star}$ & $0.330^{\star \star}$ & $0.199^{\star \star}$ & $0.265^{\star \star}$ & $0.162^{* *}$ & $0.357^{\star \star}$ & $0.465^{\star \star}$ & $0.169^{\star \star}$ & $-0.222^{\star *}$ \\
\hline 3. Change seeking & $0.192^{\star *}$ & 0.121 & 0.117 & $0.223^{\star *}$ & $0.392^{* *}$ & 0.110 & $0.136^{*}$ & -0.10 & $-0.410^{\star \star}$ \\
\hline 4. Positive reaction to change & $0.134^{\star}$ & $0.162^{\star \star}$ & $0.168^{\star *}$ & $0.287^{\star \star}$ & $0.301^{\star *}$ & $0.240^{* *}$ & $0.287^{\star \star}$ & $0.168^{* *}$ & $-0.335^{\star \star}$ \\
\hline 5. Cognitive flexibility & 0.080 & $0.256^{\star \star}$ & $0.171^{\star \star}$ & $0.193^{\star *}$ & $0.240^{\star *}$ & $0.174^{\star \star}$ & $0.151^{\star \star}$ & -0.008 & $-0.262^{\star \star}$ \\
\hline
\end{tabular}

${ }^{*} p<0.01,{ }^{*} p<0.05$. TIPI, Ten Item Personality Inventory; RSES, Rosenberg Self-Esteem Scale; SWLS, Satisfaction With Life Scale; AS, Authenticity Scale; RCS, Resistance to Change Scale.

Future studies on the topic should make use of larger samples with strict selection of the constructs to be investigated.

On the positive side, the study showed that the ACS is a brief and easily administered instrument with good psychometric properties that can be used to help people adjust to change and find their own way to manage their life and work opportunities.

Because resistance to change can be seen as a counterproductive attitude (Dent and Goldberg, 1999), we preferred to focus on acceptance of change as a productive attitude. In fact, the acceptance of change can move people from a state of immobility to a state of mobility and thereby help them meet the challenges of the twenty-first century (Di Fabio and Bernaud, 2008; Di Fabio and Maree, 2013; Di Fabio, 2015b, 2016b; Di Fabio et al., 2015) and achieve general well-being

\section{REFERENCES}

Alessandri, G., Borgogni, L., Consiglio, C., and Mitidieri, G. (2015). Psychometric properties of the italian version of the psychological capital questionnaire. Int. J. Sel. Asses. 23, 149-159. doi: 10.1111/ijsa.12103

Armenakis, A., and Bedeian, A. (1999). Organisational change: a review of theory and research in the 1990s. J. Manage. 25, 293-315. doi: $10.1177 / 014920639902500303$

Armenakis, A. A., Harris, S. G., and Mossholder, K. W. (1993). Creating readiness for organizational change. Hum. Relat. 46, 681-703. doi: $10.1177 / 001872679304600601$

Arnoux-Nicolas, C., Sovet, L., Lhotellier, L., Di Fabio, A., and Bernaud, J.-L. (2016). "Perceived work conditions and turnover intentions: the mediating role of meaning of life and meaning of work," in From Meaning of Working to Meaningful Lives: The Challenges of Expanding Decent Work. Research Topic in Frontiers in Psychology. Section Organizational Psychology, eds A. Di Fabio and D. L. Blustein. doi: 10.3389/fpsyg.2016.00704

Bentler, P. M., and Bonnet, D. C. (1980). Significance tests and goodness of fit in the analysis of covariance structures. Psychol. Bull. 88, 588-606. doi: 10.1037/0033-2909.88.3.588

Browne, M. W., and Cudeck, R. (1993). "Alternative ways of assessing model fit," in Testing Structural Equation Models, eds K. A. Bollen and J. S. Long (Newsbury Park, CA: Sage), 136-162.

Burnes, B. (2003). Managing change and changing managers from ABC to XYZ. J. Manage. Dev. 22, 627-642. doi: 10.1108/02621710310484768

Byrne, B. M. (1994). Structural Equation Modeling with EQS and EQS/Windows. Thousand Oaks, CA: Sage Publications.

Cañas, J. J., Antolí, A., Fajardo, I., and Salmerón, L. (2005). Cognitive inflexibility and the development and use of strategies for solving complex dynamic problems: effects of different types of training. Theor. Issues Ergon. Sci. 6, 95-108. doi: 10.1080/146392205123313 11599
(Di Fabio and Kenny, 2012a,b, 2015, 2016; Di Fabio and Maree, 2012; Di Fabio and Bucci, 2016; Di Fabio and Palazzeschi, 2016). In other words, the ability to accept change can be a valuable resource in many spheres of life on an intra- and inter-individual level as well as a global level, and it is hoped that the ACS will prove to be a useful tool in this endeavor.

\section{AUTHOR CONTRIBUTIONS}

$\mathrm{AD}$ conceptualized the study and choose the theoretical framework. $\mathrm{AD}$ conceptualized the new scale and realized it. $\mathrm{AD}$ and AG collected the data. AG analyzed the data and wrote the methods and results. Then all authors wrote the paper together and read and revised the manuscript several times.

Cattell, R. B. (1966). The scree test for the number of factors. Multivariate Behav. Res. 1, 245-276. doi: 10.1207/s15327906mbr0102_10

Child, J., and Kieser, A. (1981). Development of organizations over time. Handb. Organ. Design 1, 28-64.

Coch, L., and French, J. R. P. Jr. (1948). Overcoming resistance to change. Hum. Relat. 1, 512-532. doi: 10.1177/001872674800100408

Compton, W. C. (2005). An Introduction to Positive Psychology. Belmont, CA: Wadsworth.

Conner, D. R. (1992). Managing at the Speed of Change: How Resilient Managers Succeed When Others Fail. New York, NY: Villard Books.

Corwyn, R. F. (2000). The factor structure of global self-esteem among adolescents and adults. J. Res. Pers. 34, 357-379. doi: 10.1006/jrpe.2000.2291

Craparo, G., Faraci, P., and Gori, A. (2015). Psychometric properties of the 20-item Toronto Alexithymia Scale in a group of Italian younger adolescents. Psychiatry Investig. 12, 500-507. doi: 10.4306/pi.2015.12.4.500

Deci, E. L., and Ryan, R. M. (1985). Intrinsic Motivation and Self-determination in Human Behavior. New York, NY: Plenum.

Deci, E. L., and Ryan, R. M. (2000). The 'what' and 'why' of goal pursuits: Human needs and the self-determination of behaviour. Psychol. Inq. 11, 227-268. doi: 10.1207/S15327965PLI1104_01

Demers, C. (2007). Organizational Change Theories. Thousand Oaks, CA: Sage Publications Inc.

Dent, E. B., and Goldberg, S. G. (1999). Resistance to change: A limiting perspective. J. Appl. Behav. Sci. 35, 45-47. doi: 10.1177/0021886399351005

Di Fabio, A. (2011). Emotional intelligence and resistance to change: some empirical results. Rev. Psychol. Travail Organ. 17, 91-106. doi: 10.1016/S14202530(16)30135-2

Di Fabio, A. (2014a). Intrapreneurial self-capital: a new construct for the 21st century. J. Employ. Couns. 51, 98-111. doi: 10.1002/j.2161-1920.2014. 00045.x

Di Fabio, A. (2014b). Authenticity Scale: Un primo contributo alla validazione della versione italiana [Authenticity Scale: A first contribution to validation of 
the Italian version]. Couns. G. Ital. Ric. Appl. 7, 231-238. Retrieved from: http:// rivistedigitali.erickson.it/counseling/archivio/vol-8-n-3/

Di Fabio, A. (2015a). Beyond fluid intelligence and personality traits in social support: the role of ability based emotional intelligence. Front. Psychol. 6:395. doi: 10.3389/fpsyg.2015.00395

Di Fabio, A. (2015b). Positive Relational Management Scale per rilevare positività e complessità [Positive Relational Management Scale to detect positivity and complexity]. Couns. G. Ital. Ric. Appl. Retrieved from: http://rivistedigitali. erickson.it/counseling/archivio/vol-8-n-3/

Di Fabio, A. (2016a). Flourishing Scale: Primo contributo alla validazione della versione italiana. [Flourishing Scale: First contribution to the validation of the Italian version]. Couns. G. Ital. Ric. Appl. 9. Retrieved from: http:// rivistedigitali.erickson.it/counseling/

Di Fabio, A. (2016b). Life Design and Career Counseling Innovative Outcomes (CCIO): a case study. Career Dev. Q. 64, 35-48. doi: 10.1002/cdq.12039

Di Fabio, A., and Bernaud, J.-L. (2007). L' della consulenza di orientamento: Alcune evidenze empiriche in studenti di scuola superiore [The attractiveness of career counseling: Empirical evidence in high school students]. Giornale Ital. Psicol. Orientamento 7, 15-27.

Di Fabio, A., and Bernaud, J.-L. (2008). The help-seeking in career counseling. J. Vocat. Behav. 72, 60-66. doi: 10.1016/j.jvb.2007.10.006

Di Fabio, A., Bernaud, J.-L., and Loarer, E. (2014). Emotional intelligence or personality in resistance to change? Empirical results in an Italian health context. J. Employ. Couns. 51, 146-157. doi: 10.1002/j.2161-1920.2014.00048.x

Di Fabio, A., and Bucci, O. (2015). Affective profiles in Italian high school students: Life satisfaction, psychological well-being, self-esteem, and optimism. Front. Psychol. 6:1310. doi: 10.3389/fpsyg.2015.01310

Di Fabio, A., and Bucci, O. (2016). Green positive guidance and green positive life counseling for decent work and decent lives: Some empirical results. Front. Organ. Psychol. 7:261. doi: 10.3389/fpsyg.2016.00261

Di Fabio, A., and Gori, A. (2015). Measuring adolescent life satisfaction: psychometric properties of the satisfaction with life scale in a sample of italian adolescents and young adults. J. Psychoeduc. Assess. Advance online publication. doi: 10.1177/0734282915621223. [Epub ahead of print].

Di Fabio, A., Gori, A., and Giannini, M. (2016). Analysing the psychometric properties of a Big Five measure with an alternative method: The example of the Ten Item Personality Inventory (TIPI). Couns. G. Ital. Ric. Appl. Retrieved from: http://rivistedigitali.erickson.it/counseling/

Di Fabio, A., and Kenny, M. E. (2012a). The contribution of emotional intelligence to decisional styles among Italian high school students. J. Career Assess. 20, 404-414. doi: 10.1177/1069072712448893

Di Fabio, A., and Kenny, M. E. (2012b). Emotional intelligence and perceived social support among Italian high school students. J. Career Dev. 39, 461-475. doi: $10.1177 / 0894845311421005$

Di Fabio, A., and Kenny, M. E. (2015). The contributions of emotional intelligence and social support for adaptive career progress among Italian youth. J. Career Dev. 42, 48-49. doi: 10.1177/0894845314533420

Di Fabio, A., and Kenny, M. (2016). From decent work to decent lives: positive Self and Relational Management (PSandRM) in the twenty-first century. Front. Psychol. 7:361. doi: 10.3389/fpsyg.2016.00361

Di Fabio, A., and Maree, J. G. (2012). Group-based Life Design Counseling in an Italian context. J. Vocat. Behav. 80, 100-107. doi: 10.1016/j.jvb.2011.06.001

Di Fabio, A., and Maree, J. G. (eds.) (2013). Psychology of Career Counseling: New Challenges for a New Era. Festschrift in Honour of Prof. Mark Savickas. New York, NY: Nova Science Publishers.

Di Fabio, A., and Maree, J. G. (2016). "Using a transdisciplinary interpretive lens to broaden reflections on alleviating poverty and promoting decent work," in From Meaning of Working to Meaningful Lives: The Challenges of Expanding Decent Work. Research Topic in Frontiers in Psychology. Section Organizational Psychology, eds A. Di Fabio and D. L. Blustein. doi: 10.3389/fpsyg.2016. 00503

Di Fabio, A., and Palazzeschi, L. (2009). Emotional intelligence, personality traits and career decision difficulties. Int. J. Educ. Vocat. Guid. 9, 135-146. doi: 10.1007/s10775-009-9162-3

Di Fabio, A., and Palazzeschi, L. (2012). Incremental variance of the core self-evaluation construct compared to fluid intelligence and personality traits in aspects of decision-making. Pers. Individ. Dif. 53, 196-201. doi: 10.1016/j.paid.2012.03.012
Di Fabio, A., and Palazzeschi, L. (2015a). Hedonic and eudaimonic well-being: the role of resilience beyond fluid intelligence and personality traits. Front. Psychol. 6:1367. doi: 10.3389/fpsyg.2015.01367

Di Fabio, A., and Palazzeschi, L. (2015b). Multidimensional Scale of Perceived Social Support (MSPSS): Un contributo alla validazione italiana [Multidimensional Scale of Perceived Social Support (MSPSS): A contribution to Italian validation]. Couns. G. Ital. Ric. Appl. 8. Retrieved from: http:// rivistedigitali.erickson.it/counseling/archivio

Di Fabio, A., and Palazzeschi, L. (2016). Marginalization and precariat: The challenge of intensifying life construction intervention. Front. Organ. Psychol. 7:444. doi: 10.3389/fpsyg.2016.00444

Di Fabio, A., Palazzeschi, L., Levin, N., and Gati, I. (2015). The role of personality in the career decision-making difficulties of Italian young adults. J. Career Assess. 23, 281-293. doi: 10.1177/1069072714535031

Di Fabio, A., and Saklofske, D. H. (2014a). Comparing ability and self-report trait emotional intelligence, fluid intelligence, and personality traits in career decision. Pers. Individ. Dif. 64, 174-178. doi: 10.1016/j.paid.2014.02.024

Di Fabio, A., and Saklofske, D. H. (2014b). Promoting individual resources: The challenge of trait emotional intelligence. Pers. Individ. Dif. 65, 19-23. doi: 10.1016/j.paid.2014.01.026

Di Fabio, A., Saklofske, D. H., and Tremblay. P. F. (2016). Psychometric Properties of the Italian Trait Emotional Intelligence Questionnaire (I-TEIQue). Pers. Individ. Dif. 96, 198-201. doi: 10.1016/j.paid.2016.03.009

Diener, E., Emmons, R. A., Larsen, R. J., and Griffin, S. (1985). The Satisfaction With Life Scale. J. Pers. Assess. 49, 71-75. doi: 10.1207/s15327752jpa4901_13

Diener, E., Wirtz, D., Tov, W., Kim-Prieto, C., Choi, D. W., Oishi, S., et al. (2010). New well-being measures: Short scales to assess flourishing and positive and negative feelings. Soc. Indic. Res. 97, 143-156. doi: 10.1007/s11205-0099493-y

Dunican, B. (2015). Acceptance of Change: Exploring the Relationship among Psychometric Constructs and Employee Resistance. Unpublished doctoral dissertation. Bowling Green, KY: Western Kentucky University.

Folger, R., and Skarlicki, D. P. (1999). Unfairness and resistance to change: Hardship as mistreatment. J. Organ. Change Manage. 12, 35-50. doi: 10.1108/09534819910255306

Ford, J. D., Ford, L. W., and D'Amelio, A. (2008). Resistance to change: The rest of the story. Acad. Manage. Rev. 33, 362-377. doi: 10.5465/AMR.2008.31193235

Fredrickson, B. L. (2001). The role of positive emotions in positive psychology: the broaden-and-build theory of positive emotions. Am. Psychol. 56, 218-226. doi: 10.1037/0003-066X.56.3.218

Fredrickson, B. L. (2004). "Gratitude, like other positive emotions, broadens and builds," in The Psychology of Gratitude, eds R. A. Emmons and M. E. McCullough (New York, NY: Oxford University Press), 145-166.

Gagné, M., and Deci, E. L. (2005). Self-determination theory and work motivation. J. Organ. Behav. 26, 331-362. doi: 10.1002/job.322

Geller, E. S. (2002). Leadership to overcome resistance to change: It takes more than consequence control. J. Organ. Behav. Manage. 22, 29-49. doi: 10.1300/J075v22n03_04

Giannini, M., Gori, A., De Sanctis, E., and Schuldberg, D. (2011). A Comparative analysis of attachment: psychometric properties of the PTI Attachment Styles Scale (ASS). J. Psychother. Integr. 21, 363-381. doi: 10.1037/ a0025461

Goldsmith, R. E. (1984). Personality characteristics associated with adaptationinnovation. J. Psychol. 117, 159-165. doi: 10.1080/00223980.1984.9923672

Gori, A., Craparo, G., Giannini, M., Loscalzo, Y., Caretti, V., La Barbera, D., et al. (2015). Development of a new measure for assessing insight: Psychometric properties of the insight orientation scale (IOS). Schizophr. Res. 169, 298-302. doi: 10.1016/j.schres.2015.10.014

Gosling, S. D., Rentfrow, P. J., and Swann, W. B. Jr. (2003). A very brief measure of the Big Five personality domains. J. Res. Pers. 37, 504-528. doi: 10.1016/S00926566(03)00046-1

Hage, S. M., Romano, J. L., Conyne, R. K., Kenny, M., Matthews, C., Schwartz, J. P., et al. (2007). Best practice guidelines on prevention practice, research, training, and social advocacy for psychologists. Couns. Psychol. 35, 493-566. doi: 10.1177/0011000006291411

Hoag, B. G., Ritschard, H. V., and Cooper, C. L. (2002). Obstacles to effective organizational change: The underlying reasons. Leadersh. Organ. Dev. J. 23, 6-15. doi: 10.1108/01437730210414526 
Hrebiniak, L. G., and Joyce, W. F. (1985). Organizational adaptation: Strategic choice and environmental determinism. Adm. Sci. Q. 30, 336-349. doi: $10.2307 / 2392666$

Hu, L. T., and Bentler, P. M. (1999). Cutoff criteria for fit indexes in covariance structure analysis: conventional criteria versus new alternatives. Struct. Equ. Model. 6, 1-55. doi: 10.1080/10705519909540118

Huczynski, A., and Buchanan, D. (2001). Organizational Behaviour, 4th Edn. Harlow: FT/Prentice Hall.

Jordan, P. (2005). Dealing with organizational change: can emotional intelligence enhance organizational learning? Int. J. Organ. Behav. 8, 456-471.

Judge, T. A., Locke, E. A., and Durham, C. C. (1997). The dispositional causes of job satisfaction: A core evaluations approach. Res. Organ. Behav. 19, 151-188.

Judge, T. A., Thoresen, C. J., Pucik, V., and Welbourne, T. M. (1999). Managerial coping with organizational change: A dispositional perspective. J. Appl. Psychol. 84, 107-122. doi: 10.1037/0021-9010.84.1.107

Kenny, M. E., and Hage, S. M. (2009). The next frontier: prevention as an instrument of social justice. J. Prim. Prev. 30, 1-10. doi: 10.1007/s10935-0080163-7

Kirton, M. (1980). Adaptors and innovators in organizations. Hum. Relat. 33, 213. doi: $10.1177 / 001872678003300401$

Kirton, M. (ed.) (1989). Adaptors and Innovators: Styles of Creativity and ProblemSolving. New York, NY: Routledge.

Lamm, E., and Gordon, J. R. (2010). Empowerment, predisposition to resist change, and support for organizational change. J. Leadersh. Organ. Stud. 17, 426-437. doi: 10.1177/1548051809355595

Lau, C. M., and Woodman, R. W. (1995). Understanding organizational change: A schematic perspective. Acad. Manage. J. 38, 537-554. doi: 10.2307/256692

Lawrence, P. R. (1954). How to deal with resistance to change. Harv. Bus. Rev. 32, 49-57.

Lewin, K. (1952). "Group decision and social change," in Readings in Social Psychology, 2nd Edn, eds G. E. Swanson, T. M. Newcombe, and E. L. Hartley (New York, NY: Holt), 459-473.

Luthans, F., Avolio, B. J., Avey, J. B., and Norman, S. M. (2007). Positive psychological capital: Measurement and relationship with performance and satisfaction. Pers. Psychol. 60, 541-572. doi: 10.1111/j.1744-6570.2007. 00083.x

MacCallum, R. C., Browne, M. W., and Sugawara, H. M. (1996). Power analysis and determination of sample size for covariance structure modeling. Psychol. Methods 1, 130-149. doi: 10.1037/1082-989X.1.2.130

Major, B., Richards, C., Cooper, M. L., Cozzarelli, C., and Zubek, J. (1998). Personal resilience, cognitive appraisals, and coping: an integrative model of adjustment to abortion. J. Pers. Soc. Psychol. 74, 735-752. doi: 10.1037/0022-3514.74.3.735

Mallinckrodt, B., and Fretz, B. R. (1988). Social support and the impact of job loss on older professionals. J. Couns. Psychol. 35, 281-286. doi: 10.1037/00220167.35.3.281

Maslow, A. (1954). Motivation and Personality. New York, NY: Harper.

Michel, A., By, R. T., and Burnes, B. (2013). The limitations of dispositional resistance in relation to organizational change. Manage. Decis. 51, 761-780. doi: $10.1108 / 00251741311326554$

Miller, V. D., Johnson, J. R., and Grau, J. (1994). Antecedents to willingness to participate in a planned organizational change. J. Appl. Commun. Res. 22, 59-80. doi: 10.1080/00909889409365387

Nunnally, J. C., and Bernstein, I. H. (1994). Psychometric Theory, 3rd Edn. New York, NY: McGraw-Hill.

Oreg, S. (2003). Resistance to change: Developing an individual differences measure. J. Appl. Psychol. 88, 680-693. doi: 10.1037/0021-9010.88.4.680

Oreg, S. (2006). Personality, context, and resistance to organizational change. Eur. J. Work Organ. Psychol. 15, 73-101. doi: 10.1080/13594320500451247

Piderit, S. K. (2000). Rethinking resistance and recognizing ambivalence: A multidimensional view of attitudes toward an organizational change. Acad. Manage. Rev. 25, 783-794. doi: 10.5465/AMR.2000.3707722

Prezza, M., Trombaccia, F. R., and Armento, L. (1997). The Rosenberg Self-Esteem Scale: Italian translation and validation [La scala dell'Autostima di Rosenberg: traduzione e validazione Italiana]. Appl. Psychol. Bull. 223, 34-44.

Rosenberg, M. (1965). Society and the Adolescent Self-Image. Princeton, NJ: Princeton University Press.
Schermelleh-Engel, K., Moosbrugger, H., and Muller, H. (2003). Evaluating the fit of structural equation models: Tests of significance and goodness-of-fit models. Methods Psychol. Res. 8, 23-74.

Scott, W. A. (1962). Cognitive complexity and cognitive flexibility. Sociometry 25, 405-414. doi: $10.2307 / 2785779$

Seligman, M. E., and Csikszentmihalyi, M. (2000). Positive Psychology: An Introduction. Washington, DC: American Psychological Association.

Shaw, J. B., Fields, M. W., Thacker, J. W., and Fisher, C. D. (1993). The availability of personal and external coping resources: Their impact on job stress and employee attitudes during organizational restructuring. Work Stress 7, 229-246. doi: 10.1080/02678379308257064

Steiger, J. H. (1990). Structural model evaluation and modification: An interval estimation approach. Multivariate Behav. Res. 25, 173-180. doi: $10.1207 / \mathrm{s} 15327906 \mathrm{mbr} 250244$

Taylor, S. E., and Brown, J. D. (1988). Illusion and well-being: A social psychological perspective on mental health. Psychol. Bull. 103, 193-210. doi: 10.1037/0033-2909.103.2.193

Topping, P. (2002). Managerial Leadership. New York, NY: McGraw Hill Professional.

Vakola, M., Tsaousis, I., and Nikolaou, I. (2004). The role of emotional intelligence and personality variables on attitudes towards organizational change. J. Manage. Psychol. 19, 88-110. doi: 10.1108/0268394041052608

Van den Heuvel, M., Demerouti, E., Bakker, A. B., and Schaufeli, W. B. (2013). Adapting to change: the value of change information and meaning-making. J. Vocat. Behav. 83, 11-21. doi: 10.1016/j.jvb.2013.02.004

van Dam, K., Oreg, S., and Schyns, B. (2008). Daily work contexts and resistance to organisational change: The role of leader-member exchange, development climate, and change process characteristics. Appl. Psychol. 57, 313-334. doi: 10.1111/j.1464-0597.2007.00311.x

Vera-Villarroel, P., Urzúa, M. A., Pavez, P., Celis-Atenas, K., and Silva, J. (2012). Evaluation of subjective well-being: analysis of the satisfaction with life scale in Chilean population. Universitas Psychol. 3, 719-727.

Visser, C. F. (2010). Self-determination theory meets solution-focused change: autonomy, competence and relatedness support in action, interaction. J. Solut. Focus Organi. 2, 7-26.

Wanberg, C. R., and Banas, J. T. (2000). Predictors and outcomes of openness to changes in a reorganizing workplace. J. Appl. Psychol. 85, 132-142. doi: 10.1037/0021-9010.85.1.132

World Medical Association (WMA) (2013). World Medical Association Declaration of Helsinki ethical principles for medical research involving human subjects. J. Am. Med. Assoc. 310, 2191-2194. doi: 10.1001/jama.2013.281053

Wood, A. M., Maltby, J., Caliousis, M., Linley, P. A., and Joseph, S. (2008). The authentic personality: A theoretical and empirical conceptualization and the development of the authenticity scale. J. Couns. Psychol. 55, 385-399. doi: 10.1037/0022-0167.55.3.385

Zander, A. F. (1950). Resistance to change-Its analysis and prevention. Adv. Manage. 4, 9-11.

Zimet, G. D., Dahlem, N. W., Zimet, S. G., and Farley, G. K. (1988). The multidimensional scale of perceived social support. J. Pers. Assess. 52, 30-41. doi: 10.1207/s15327752jpa5201_2

Zimet, G. D., Powell, S. S., Farley, G. K., Werkman, S., and Berkoff, K. A. (1990). Psychometric characteristics of the multidimensional scale of perceived social support. J. Pers. Assess. 55, 610-617. doi: 10.1207/s15327752jpa5503\&amp;4_17

Zuckerman, M. (2014). Sensation Seeking (Psychology Revivals): Beyond the Optimal Level of Arousal. New York, NY: Psychology Press.

Conflict of Interest Statement: The authors declare that the research was conducted in the absence of any commercial or financial relationships that could be construed as a potential conflict of interest.

Copyright (c) 2016 Di Fabio and Gori. This is an open-access article distributed under the terms of the Creative Commons Attribution License (CC BY). The use, distribution or reproduction in other forums is permitted, provided the original author(s) or licensor are credited and that the original publication in this journal is cited, in accordance with accepted academic practice. No use, distribution or reproduction is permitted which does not comply with these terms. 